found that Allen fit the picture except for her sex but that she "did not have a large enough constituency to demand the recognition of a Supreme Court seat" (1981a).

While exploring the politics and context governing selection of women judges, Cook also examined the impact of gender on judicial decision making. Both Gayle Binion and Sue Davis emphasized the contributions Cook has made to feminist jurisprudence, feminist social history, and judicial behavior. Davis suggested that Cook's most important contribution has been in the agenda she has set for the study of women judges as decision makers. In articles published in $1980,1981 \mathrm{~b}$, and 1988, she explored whether women judges would make a difference in cases of equality and women's rights; her results, not surprisingly, were mixed. In asking whether women judges decide differently from their male counterparts-either in outcomes or in their methods of reasoning Cook was asking, beginning in 1980 , the questions that scholars are still trying to answer now.

In sum, Cook has improved our understanding of judges and their decisions through her attention to the impact of socialization, to political culture and public opinion, to judicial selection, and to the difference gender makes. She continues to be an active researcher with two very different publications just in the last few months. In the JPO (1993a), Cook proposes a new measure for identifying the "significant" cases of the U.S. Supreme Court, while in Judicature (1993b) she documents and analyzes the fascinating career of Georgia Bullock, the first woman judge in California.

Having contributed so much already to the field of judicial politics, Beverly Blair Cook now provides us with a wonderful addition in the following article. In "Ghosts and Giants in Judicial Politics," she turns her attention from the history of women judges to the history of women political scientists studying judges and the legal process. We thank her for this and for all her contributions to political science.

\section{Selected Publications by Beverly Blair Cook}

1967. The Judicial Process in Califormia. Belmont, CA: Dickenson (Wadsworth) Publishing.

1971. "The Socialization of New Federal Judges: Impact on District Court Business," Washington University Law Quarterly Spring, 253-79.

1972. "Role Lag in Urban Courts," Western Political Quarterly 25:234-48.

1973. "Sentencing Behavior of Federal Judges: Draft cases 1972," Cincinnati Law Review, 42:597-633.

1977. "Public Opinion and Federal Judicial Policy." American Joumal of Political Science 21:567-600.

1979. "Sentencing Problems and Internal
Court Reform,"' in The Study of Criminal Courts, ed. Peter Nardulli. Cambridge, MA: Ballinger Press.

1980. "Women Judges and Public Policy on Sex Integration," in Women in Local Politics, ed. Debra W. Stewart. Metuchen, NJ: The Scarecrow Press.

1981a. "The First Woman Candidate for the Supreme Court," Supreme Court Historical Society Yearbook, 1981, 19-35.

1981b. "The Impact of Women Judges upon Women's Legal Rights: A Prediction from Attitudes and Simulated Behavior" in Women, Power, and Political Systems, ed. M. Rendel. New York: St. Martin's Press.

1983. "Sentencing the Unpatriotic: Federal Trial Judges in Wisconsin during Four Wars," in The Quest for Social Justice, ed. Ralph Aderman. Madison: University of Wisconsin Press.

1984a. "Women Judges: A Preface to their History," Women's Forum, Golden Gate Law Review 14:573-610.

1984b. "Women on the State Bench: Correlates of Access" in Political Women: Current Roles in State and Local Politics, ed. Janet Flammang. Madison: University of Wisconsin Press.

1986. "Women Judges in the Opportunity Structure," in Women, the Courts, and Equality, ed. L. Crites and W. Hepperle. Sage Yearbook in Women Policy Studies.

1988. Women in the Judicial Process (with L. Goldstein, K. O'Connor, and S. Talarico). Washington, DC: APSA.

1991. "Justice Sandra Day O'Connor: Transition to a Republican Court Agenda." In The Burger Court, ed. Charles M. Lamb and Stephen C. Halpern. University of Illinois Press.

1993a. "Measuring the Significance of Supreme Court Decisions." The Journal of Politics 55:1127-39.

1993b. "Moral Authority and Gender Difference: Georgia Bullock and the Los Angeles Women's Court." Judicature 77:14455.

\title{
Ghosts and Giants in Judicial Politics
}

\section{Beverly B. Cook, Professor Emeritus, University of Wisconsin-Milwaukee}

\author{
A scientist who receives a prize \\ has a conventional modest dis- \\ claimer: I am standing on the \\ shoulders of giants. My response to \\ being honored by this panel is to \\ point to two lines of predecessors, \\ on whose scholarship I have tried \\ to build. One is a line of male giants; \\ the other a line of female ghosts. \\ I begin with the giants (Good- \\ now, Corwin, and Schubert) and \\ proceed with the ghosts-two
}

women (Breckinridge and Paul) who were invisible to the discipline, although giants in their own arenas, and one (Williams) who disappeared. The scarcity of giants and ghosts locates them at the tails of the natural curve; on the two curves are the productive scholars and the radical innovators and at the peak the teachers who interpret the others' writings for students.

\section{The Giants of Judicial Politics}

The identification of a giant depends upon one's own definition of the subfield. ${ }^{1}$ My preference for "judicial politics" over "law and courts," for hands-on data collection over canned computer files, and for statistical analysis over logical exegesis leads me to the first giant in my chain. Frank J. Goodnow (b. 1860) broke sharply from 


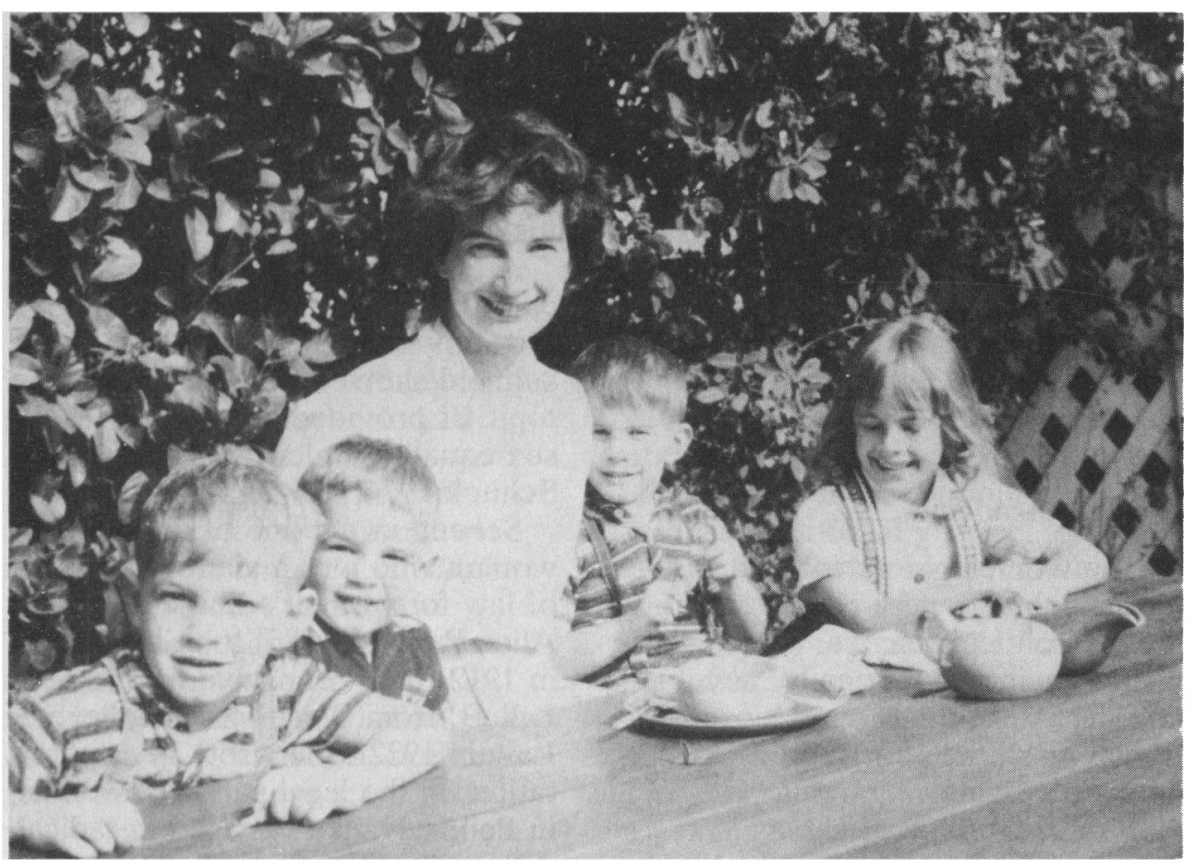

Beverly B. Cook-Preparing to return to graduate school-1959

the tradition of abstract theorizing about law and state to offer empirical descriptions of the making of constitutional and administrative law. He understood the connection between political motives and decisions.

The second giant is Edward $\mathbf{S}$. Corwin (b. 1878) who significantly

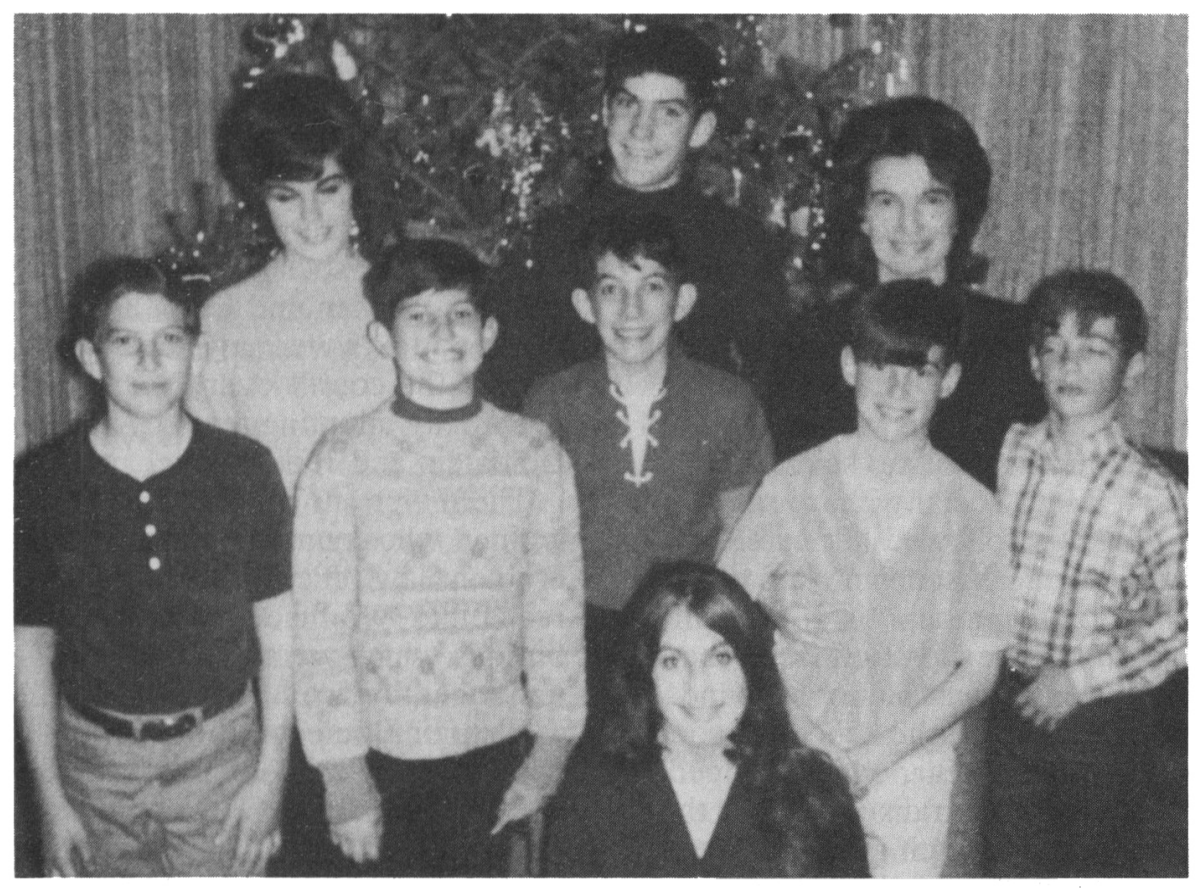

Beverly B. Cook-First semester at University of Wisconsin-Milwaukee, 1967. courts. Carl Brent Swisher is the earliest productive scholar with whom I had personal contact when he taught a seminar in constitutional history in summer 1953. Barefoot and pregnant in California, I scraped up the $\$ 25$ to register as an auditor; when I returned to graduate school in 1960, I carried his views of the relationship between a justice's life experiences and Court opinions.

Several radical innovators belong in the line of giants. Charles Groves Haines (b. 1879), Rodney L. Mott (b. 1896), and Cortez A. M. Ewing (b. 1896), whose choice of subject matter, data and/or method in work published in the $1920 \mathrm{~s}-1930$ s were generations ahead of their time. Their treatment of the personal backgrounds of judges as important predictors of their behavior entered the mainstream in 1959 with John Schmidhauser's portrait of the justices. I will never forget the stimulation of the seminar that John arranged at the University of Southern California where I presented my work-in-progress on the relationship of public opinion and draft decisions. He invited two judges, a female federal circuit judge and a male state appellate justice, to react to my findings and participate in the discussion with his graduate students.

Haines and Mott also began to broaden the scope of the subfield by treating state and local judges as appropriate subjects of study. However, the era of the uppercourt myth in the federal courts did not end until 1961 when a productive modern scholar described the behavior of federal district judges within their political environments. Jack Peltason's monograph inspired my interviews ten years later with the trial judges in the seventh circuit. I treated his 1955 textbook as a model for my 1967 book on the California judicial process. I knew Jack in California when the new Irvine and Fullerton faculties socialized, and I welcomed his legitimization of work on state courts and lower judges, because my domestic duties circumscribed my research boundaries.

At first I worked within state lines, sending a survey to the trial 
judges in California in 1964 and interviewing Kansas trial judges in 1967. By 1972 my farthest research outpost was the Southern District of Indiana in Indianapolis; I was able to fly in mornings to interview judges and return to Milwaukee at night to check the seven children at home (the eighth was away at college). In 1978 I left home long enough to interview women judges from New York City to Los Angeles, in preparation for a national survey by mailed questionnaire.

Harold Lasswell (b. 1902) was a giant in some subfields but an innovator in judicial behavior. He used psychoanalytical theory and method to establish a relationship between judicial personality and courtroom behavior. His brand of micro-analysis required a skill for which few cared to train, but he pointed to a path followed by Schubert.

The last giant is Glendon Schubert (b. 1918), whose contemporary paradigm completed the project begun by Goodnow of reversing the formalism and institutionalism of the founders. His theory was not bound to American uniqueness, since its social psychological roots invited cross-cultural studies. $\mathrm{He}$ substituted sophisticated statistical methods for Herman Pritchett's simpler methodological innovation. His research provided the major direction for subfield work from the 1950 s into the $1980 \mathrm{~s}$, through the productive scholars who adopted his framework (Sidney Ulmer, Harold Spaeth, and their students). Glen gave me my first opportunity to become professionally active beyond my campus, when he put me on a panel at the 1966 annual meeting of the Western Political Science Association. Only with my membership on the Board of Overseers of the NSF Supreme Court Data Collection Project have I addressed his theory critically and prepared to publish on the Supreme Court.

\section{The Line of Ghosts}

I found no women giants in the subfield in academia. ${ }^{2}$ Very few early women who selected public law topics for their dissertations were offered faculty positions. Their options were limited: to transfer their skills to a femaledominated discipline; to accept positions with low pay and little recognition in research institutes; to teach at women's or junior colleges; or to disappear into a private life (Cook 1984).

\section{Early Women in the Subfield Outside Academia}

The women giants with Ph.D.'s in the subfield were ghosts to academic political science. They established their reputations by developing the intellectual foundations of social work or by organizing for women's rights.

First in my line of ghosts is Sophonisba Breckinridge (b. 1866), who took her Ph.D. in 1901 in public law and her J.D. in 1904 at the University of Chicago. ${ }^{3}$ The Chicago department invited her to teach a few courses but rejected the idea of sex integration of its tenure-track faculty. In 1920 she was instrumental in establishing the Graduate School of Social Service Administration at Chicago, where she took a named chair in 1929. Her program combined political science, law, economics, statistics, and public policy and her subjects were the law of the poor, delinquent, and alien, and judicial process and court statistics, the topics of urban law that are salient today. To prepare her students for social work she developed materials and books that included a report of the first ten years of the Chicago juvenile court and Marriage and the Civil Rights of Women (1933) (Scott 1971). Other women excluded from political science moved into social welfare schools. ${ }^{4}$

I almost followed her career route when Wisconsin claimed in 1969 to have a nepotism rule which would bar me from tenure in the same department as my husband. I transferred into the school of social welfare for a year, while I helped the university to discover that the rule was unwritten and in any case contradicted federal law. Like Breckinridge, I repeated the courses in trial courts and judicial process that I offered in my own department. The experience had its benefits, introducing me to welfare case law and providing a personal incentive for studying the legal status of women.

A few women political scientists contributed to the literature on politics of women's rights. ${ }^{5}$ Men in the subfield showed little interest in the topic or provided arguments against sex equality under law (Shanley \& Schuck 1974, 633-36).

Second in my line of ghosts is a woman who was a giant in the use of law for women's liberation.

Alice Paul (b. 1885) took her Ph.D. in 1912 from Pennsylvania and her L.L.B. from Washington College of Law in 1922. She wrote her dissertation on the legal status of women in Pennsylvania, engaged in radical suffrage politics in England and the United States, and after 1920 prepared and lobbied for gender-neutral laws. She founded the American Woman's Party and wrote the original version of the Equal Rights Amendment (Lunardini 1991).

Breckinridge also made a contribution to the literature on women in law and politics in her study of the impact of women's interest groups on public policy (a precursor of Karen O'Connor's original research on women's interest groups in court). In titling her book Women in the Twentieth Century, Breckinridge connected her research to Woman in the Nineteenth Century (1845) by Margaret Fuller, a giant who wrote on women in public life before the professionalization of the social sciences. I first taught "Women and Law" in 1972 when no texts were available and offered the course every year, eventually adopting texts by Leslie Goldstein and Judith Baer.

There were no giants among the women who found positions in government law offices or research bureaus, but two made major contributions which were generally unnoticed by academics. ${ }^{6}$

Eleanor Bontecou (b. 1891) took her Ph.D. from Brookings in 1928, after earning a J.D. at New York University in 1917 . The faculty position available to her in 1930 was in Breckinridge's social welfare 
school at Chicago, but she left after one year for private practice and later the U.S. Justice and War Departments. At Cornell Research Institute in Civil Liberties, she wrote The Federal Loyalty Security Program (1953), which was one of my sources for a graduate seminar paper.

M. Louise Rutherford (b. 1892) took her Ph.D. from Pennsylvania in 1936, after earning an L.L.B. from Temple in 1921. Her dissertation was published as The Influence of the American Bar Association on Public Opinion and Legislation (1937). Her motivation, like Pound's, for describing structure and policy was reform. She was president of the Pennsylvania Political Science Association, but her career was in the private practice of law, party politics, and public office.

\section{Early Faculty Women in the Subfield}

A few women in the generations before 1920 found faculty positions and "materialized" in the subfield by publishing their research findings. No one was recruited by a prestigious department, and no one attained the stature of a giant. Most faculty women were invisible, teachers in small colleges, who did not publish. Women graduate students with an interest in public law had few female mentors until the 1980s. The professors and the students at my two graduate departments were all male. I never met a subfield woman of an earlier generation and know only two women from my own cohort (M. C. Porter and Kathleen Barber).

Nine of these early women found positions in coeducational schools; two were visible and productive scholars and seven were teachers. ${ }^{7}$ Miriam Oatman (b. 1887) earned her Ph.D. from Brookings in 1930. Her career was peripatetic, on faculties from Washington, D.C. to California and in various government bureaus. Her research interests included administrative law and adjudication. She published in Public Administration Review, Political Science Quarterly, Law and
Contemporary Problems, and law reviews.

Eleanore Bushnell (b. 1913) took her Ph.D. at University of California-Berkeley in 1952, writing her dissertation on "A Study of Federalism in Australia with Emphasis upon the High Court's Interpretation of Federal Powers." She was tenured at San Francisco State but moved in 1956 to the University of Nevada where she became a full professor in 1958 and recently took emeritus status. Her books treat state constitutional change, the impact of reapportionment, and impeachment trials of federal judges. She was active in the Western Political Science Association and is currently a member of the APSA Law and Courts Section.

Five early women found a niche in women's colleges; the first women with Ph.D.'s to teach public law were nuns. ${ }^{8}$ Two professors, both at Hunter, contributed to scholarship on the courts. Margaret Spahr (b. 1893) took her Ph.D. in 1926 and an L.L.B. in 1929 from Columbia. Her dissertation on the Supreme Court and taxation was published in 1926. She wrote for law reviews and had two articles in APSR in 1930 and 1945. She went to Hunter in 1925 and retired as professor emeritus in 1960.

Ruth G. Weintraub (b. 1905) took her Ph.D. from Columbia in 1939, after earning a J.D. at New York University in 1931. She was an instructor at Hunter in 1929, full professor in 1951, chair in 1956, director of graduate studies in 1960, and dean of social sciences in 1968. Her public law books include her dissertation, Government Corporations and State Law (1939) and How to Secure These Rights (1949). She also published in the APSR, Journal of Criminal Law and Criminology, and Social Service Review. She was very active in the organized profession, serving on the APSA nominating committee and on its council.

At the Seven Sisters, where women Ph.D.s had some entitlement to faculty positions and gained recognition from the organized profession, few subfield women were tenured. ${ }^{9}$ Breckinridge was a student at Wellesley in the $1880 \mathrm{~s}$, and her teacher of constitutional history was a male lawyer (Cook 1981). When I was at Wellesley in the 1940s, the assigned faculty member was the token man in the department.

Third in my line of ghosts is Charlotte Williams (b. 1916), who took her Ph.D. from Johns Hopkins in 1949. She taught at the Woman's College of the University of North Carolina and Smith College before taking her degree and was assistant professor at Wellesley for one year (1949-50). ${ }^{10}$ She taught for a short period at Middle Tennessee. A student of Swisher, she was the first woman to take a behavioral perspective on the opinions of a justice in her published dissertation, Hugo Black: A Study in Judicial Process (1950).

\section{Explaining the Invisible Academic Women}

Why were there so few academic women in the first generations of "public law" specialists? One explanation is that the subfield was established as the core of the discipline. It is difficult for female outsiders to break into groups with a long tradition of male monopoly. Second, the subfield was closely associated with the legal profession, which also has a history of female exclusion. Women who sought to enhance their opportunities with a law degree $(40 \%$ of the early women) did not find alternatives on law school faculties. For the same reasons jurisprudence was not a female domain; Spahr in 1926 was the first to publish on doctrine.

The concentration of women's interest in policy and process in preference to legal theory and judicial behavior persists in the latest cohorts. The fact that women were not competing with male scholars over traditional terrain gave them some places outside the best departments which men did not covet. The fragmentation of the subfield, which began in the 1960 s with Nagel's research on state supreme courts and Jacob's on state trial court actors, offered to newcomers fresh topics of research and courses to teach, but also reduced 
the likelihood of national attention to their work. The boundaries on theory and conceptualization for judicial doctrine and behavior are sharper than for process; those entering the subfield in the 1960 s faced a difficult task of scholarship with small predictable payoffs.

The sense that public law was a male domain lasted well into the 1970 s, shaping the attitude of men recruiting for open positions. Following is a typical statement in the literature: "Who are the men, judged by those who are knowledgable in the field, considered to be the innovative scholars?" (deGrazia and Ruttenberg 1963, 48). Becker $(1970,163)$ anticipated a "large, scientifically oriented group of men" to become engaged in judicial politics.

Another explanation applies to early women in every profession. Women were expected to choose between a professional and a family life. Only $17 \%$ of the subfield women born before 1900 married; the percentage doubled in the next generation; and doubled again to $65 \%$ for my 1920 s cohort. In succeeding cohorts the married proportion has remained over $50 \%$. Cultural norms that prevented wives and mothers from working were somewhat weaker by the 1960 s, but I kept my private life strictly segregated from my university role to avoid any questioning of my professional commitment.

The 1920s cohort had special opportunities to gain positions, if not recognition, in academia. In the late 1940s the GI bill brought veterans to campus, and departments needed teachers for basic courses. The academic door cracked open for me at Iowa State in 1949-50 where I taught American Government to large classes. It closed again as the domestic culture of the $1950 \mathrm{~s}$ strongly affected my social role.

In the Great Society era, government-supported higher education expanded again to serve the demand for academic credentials. In the competition for qualified students, new graduate departments admitted women with some enthusiasm, and the expansion in number and size of faculties and

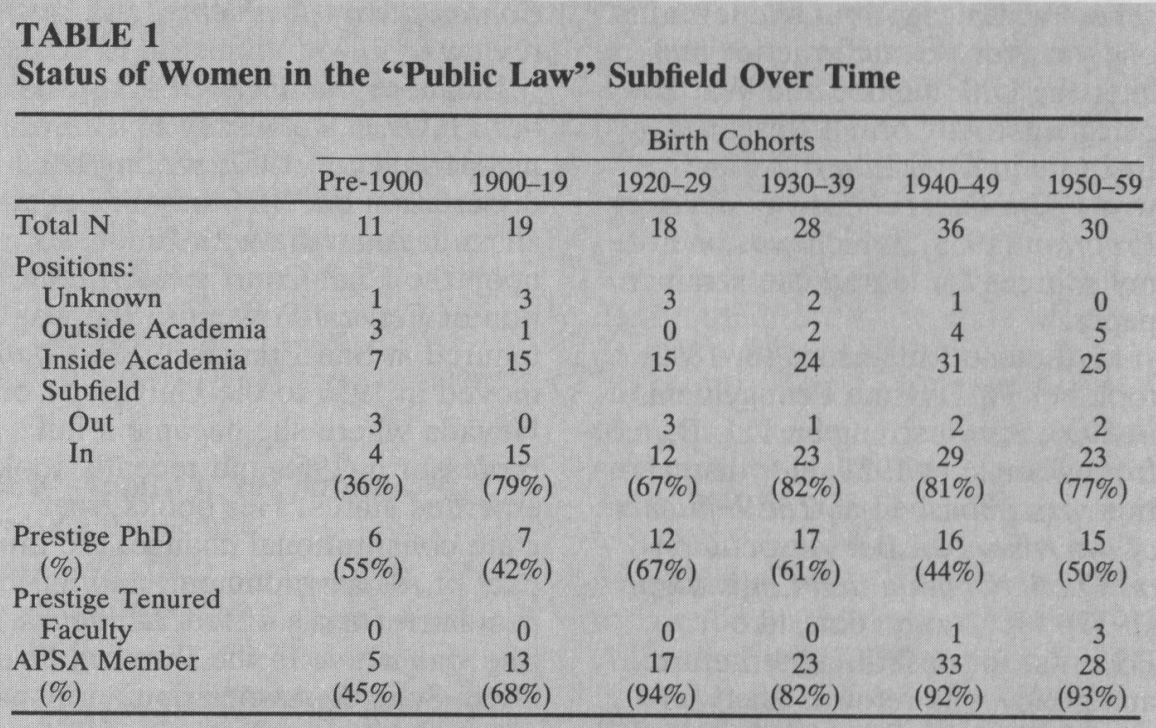

Note: Prestige graduate department lists from Somit and Tanenhaus (1967) and Rudder (1983). Outside the subfield in academia includes a change of subfield in the political science department, a different department or unit, or long-term administrative position.

courses provided places for a few more women professors.

The women's movement beginning in the 1960 s encouraged women to expect that their credentials would have the same value as men's in the marketplace. With my degree in hand in 1962, a position at California State at Fullerton, to teach in a quonset hut where orange trees had stood the year before, was an appropriate place to begin my career.

\section{The Integration of the Chain}

How does the contemporary status of academic women in the subfield compare to past generations? Table 1 shows that the proportion of women invited into academia doubled from the first to the second generation and then remained steady. There has been no relationship between the proportion of women with prestigious degrees and their faculty positions. No woman born before 1940 was tenured by a prestigious department. ${ }^{11}$

The first woman in the subfield to gain tenure in such a department was retained by her own professors (Susan Rose-Ackerman at Yale). Three women in the 1950 s cohort have tenure in the best departments (Jennifer Hochschild at Princeton; Kim Lane Scheppele at Michigan; and Lee Epstein at Washington
University). Fifteen of the top departments do not have a strong subfield faculty (defined as three tenured members of the Law and Courts Section with a publication list). Of the five which do-Ohio State, Minnesota, Northwestern, University of California-Berkeley, and Wisconsin, only Wisconsin has a woman on tenure track.

Some doctoral departments of lesser rank have built strong faculties in the subfield. Michigan State and Kentucky deserve their reputations for training doctoral candidates. Other excellent departments include Delaware, Emory, Georgia, Massachusetts, UC-Santa Barbara, Rutgers, SUNY-Albany, and Texas A\&M. Of the ten mentioned above, six have faculty women. Of the $100+$ doctoral departments with at least one subfield professor in 1992, about $35 \%$ have one or more women. The best liberal arts colleges, like the best graduate programs, have kept their male hegemony. Of the Section members with tenure at ten top-ranked liberal arts colleges, only one is a woman (Lynn Mather at Dartmouth).

While the proportion of subfield women who found places in academia and joined APSA increased after 1900 , the proportion of subfield scholars who are women has changed little. Based on first choice subfields (judiciary; constitutional 
law or history; administrative law) in the 1967 APSA survey (Eulau 1969), women made up $20 \%$ of the pre-1930 cohort. Approximately $20 \%$ of faculty members in the 1992 Section directory are women. The larger proportion of women in the discipline is not mirrored in the subfield.

The gender of recipients of awards, grants, and special assignments signals the increasing visibility of women. The Corwin dissertation award went to a woman in 1985, 1986, and 1991. Several women have served as Judicial Fellows in Washington, D.C., a highly selective opportunity to work with the federal courts for a year. Books, chapters, and articles by women have increased in number, and membership in APSA, an indicator of professionalism, is high.

However, the emergence of a giant in the subfield and the giant's gender are unpredictable. The new title of the Section-Law and Courts-indicates that a majority of members expect the next giant to create a paradigm that turns back from behavioralism to institutionalism without abandoning a strong empiricism. The trend from Goodnow to Schubert was to narrow the focus of the subfield and to reduce the number of concepts and tools. No subfield giant has failed to focus on Supreme Court justices and significant national policy issues. The contemporary fragmentation of the subfield demands that the next giant take account of the dramatic expansion of subject matter by developing a larger array of concepts and methods and by formulating a broad synthesis through new empirical or legal theory.

\section{Notes}

1. Somit and Tanenhaus (1964, 66-69) offer five alternative standards for eminence. I adopt their second definition-the systematizer of a subfield in the image of his own thought. In their "ranking of great men" prior to 1945, Corwin is fifth and Goodnow 11th.

2. Sources of data on women in the subfield include dissertation abstracts, using key words to search the volume for political science and law; the APSA biographical directories, 1945 to date, and Graduate Faculty and Programs in Political Science, rev. 14th ed.; the lists of dissertations completed in the American Political Science Review beginning with volume 4 (1910); the directories of the Section; the comprehensive bibliographies of Henry Abraham and Glendon Schubert and citations in public law textbooks; and Notable American Women and other who's whos of women. I identified a woman with the subfield if she belonged to the Section, or wrote her dissertation in the subfield, or taught and published in the subfield.

I use birth cohorts to distinguish my predecessors from my own (1920s) and successive cohorts. An alternative categorization is by date of doctoral degree. It seemed to me that the end of a full career was more closely related to birthdate than degree date and that scholars tend to be judged with their age peers.

3. Breckinridge, as well as Oatman and Bontecou, discussed below, were in the set of only five women invited to contribute to the International Encyclopedia of the Social Sciences (1930-35).

4. Not a giant but a major contributor to social work education, Kate Holladay

Claghorn (b. 1871) took her political science $\mathrm{Ph.D}$. at Yale in 1896, writing her dissertation on "Law, Nature, and Convention: a Study in Political Theory." Her academic appointment at New York University was not in political science but in the School of Social Work. Her books were Juvenile Delinquency in Rural New York (1918) and The Immigrant's Day in Court (1923). Breckinridge and Claghorn were the first two women to take public law doctorates.

Three women with similar interests in judicial administration were ghosts to the discipline after taking their Ph.D.s-Gertrude E. Smith (Chicago 1921), Hilda Neatby (Minnesota 1934), and Mary Stanton (Chicago 1944).

5. Women whose doctoral research was on women and law were ghosts in the subfield. Ruth Gallaher (b. 1882) took her Iowa Ph.D. in 1918, writing her dissertation on the legal status of women in Iowa. This work was published by the state historical society where she did research and wrote reports for 34 years; only at the end of her career did she finally achieve her dream of a professorship at a small college. Caroline J. Gleason (b. 1886) wrote her dissertation at Catholic University on "Legislation for Women in Oregon"; it was printed as a bulletin of the U.S. Women's Bureau in 1931.

Marguerite Fisher (b. 1901) took her degree from Syracuse in 1941, writing on the relationship of the FBI to state and local law enforcement. She joined the faculty of her own doctoral department. She published her research on the legal status of women as jurors and worked for women's rights in her community.

6. Ruth Locke Roettinger (b. 1904) took her Ph.D. from North Carolina in 1956; her dissertation was on "The Supreme Court and the Police Power of the States, 19301956: a Study in Federalism." She became the director of the American Association of University Women fellowship program in Washington, D.C.

7. Elsa deHaas (b. 1901) took her Ph.D. degree from Columbia in 1929, writing her dissertation on English criminal cases to 1275. She taught across the fields at Brooklyn College beginning in 1930.

Georgia H. Wilson (b. 1905) began teaching at Brooklyn after she took a D.Juris. from New York University in 1930. She was promoted to assistant professor in 1955.

Edna R. Fluegel (b. 1912) took her Ph.D. at Duke in 1938 and wrote her dissertation on "Concepts of Economic Liberty and the U.S. Supreme Court: a Study in Judicial Thought." She taught at Trinity for 24 years, but after serving in the State Department, her research interests turned to foreign policy.

Josephine Pisani (b. 1913) took her LL.B. in 1936 and Ph.D. in 1941 from Fordham. She taught at Queens beginning in 1943.

Harriet Berger (b. 1917) took her Ph.D. from Pennsylvania in 1967 and began teaching at Drexel Institute that year. Her dissertation was on Justice Harlan and police power. She is a member of the Law and Courts Section now.

Rita W. Nealon (b. 1919), Ph.D. 1949 from New York University, wrote her dissertation on "Contributions of the Attorneys-General to the Constitutional Development of the American Presidency." She taught at NYU beginning in 1944 and published in the NYU Law Quarterly.

Marguerite J. Fisher, who had a full teaching career at Syracuse, was discussed with women who wrote on women's rights.

8. Barbara McCarthy (b. 1878) took her $\mathrm{Ph}$.D. from Catholic University in 1928 writing her dissertation on "The Widening Scope of American Constitutions." She taught at Nazareth College in Michigan beginning in 1924. Caroline Gleason, described for her study of women's legal status, was also a nun at a small college.

Mary Capen Davis (b. 1913) took her 1940 Ph.D. from Radcliffe, writing her dissertation on "The Nature and Development of Political Responsibility with particular reference to Judicial Functions." She was an instructor at Hunter in 1942 and at New Jersey College for Women in 1944.

Clara A. Molendyk wrote her dissertation on Charles Evans Hughes at Fordham (1936) but then disappeared from professional sight.

9. Phoebe Morrison (b. 1902) took an SJD from Yale in 1928 and then worked as research associate there, for the U.S. government, and in research bureaus until offered a tenured position at Barnard in 1952. She became full professor in 1960 . For one year (1939-40) she was a probate judge in Connecticut.

10. When I interviewed her for the APSA oral history project, Miss Overacker, who was chair of the Wellesley department, said that she wanted to put Williams on tenure track but there was no budgeted position.

11. The rank of a department was ascertained by fitting dates from individual biographies to the lists provided by Somit and Tanenhaus (1964) and Rudder (1983). I included as prestigious the first ten on the 1925 list, 15 from the 1957 list, and 20 from the 1963 and 1981 lists. 


\section{References}

Becker, Theorore L. 1970. "Judicial Theory." In Approaches to the Study of Political Science. Michael Haas and Henry S. Kariel, eds. Scranton: Chandler Publishing Co.

Cook, Beverly B. 1981. "Sunday Letters Home: Tensions between Affection and Convention." Unpublished paper. . 1984. "Early Women in Political Science: the Personal Side." Paper delivered at annual meeting of Western Political Science Association, Sacramento, April 12-14.

. 1986. "Support for Academic

Women in Political Science, 1890-1945." Women and Politics 6 (Fall 1986) 75-104.
deGrazia, Alfred, and Charles L. Ruttenberg. 1963. "Innovators in the Study of the Legal Process." The American Behavioral Scientist 7:48-52.

Eulau, Heinz. 1969. "Quo Vadimas?” PS 2:12-13.

Lunardini, Christine A. 1991. "Alice Paul, 1885-1977," in Portraits of American Women. G. J. Barker-Benfield and Catherine Clinton, eds. New York: St. Martin's Press.

Rudder, C. E. 1983. "The Quality of Graduate Education in Political Science." PS 16:48-52.

Shanley, Molly L., and Victoria Schuck. 1974. "In Search of Political Woman." Social Science Quarterly 55:632-44.

Somit, Albert, and Joseph Tanenhaus. 1964.
American Political Science: A Profile of the Discipline. New York: Atherton Press.

. 1967. The Development of Political Science. Boston: Allyn and Bacon, Inc.

\section{About the Author}

Beverly B. Cook is professor emeritus, University of Wisconsin-Milwaukee, and since 1989 divides her time between the computer and the pool in California.

\title{
How to Select a Publisher in Political Science
}

\author{
Christopher J. Kelaher, The American University Press \\ Edward Artinian, Chatham House Publishers
}

The questions most frequently asked of editors are "How do I get my book published?" and "Who should I talk to about my manuscript or project?'” To help prospective authors, we have compiled the following list of publishers and editors working in political science. Criteria for inclusion in this list are attendance and exhibits at major academic meetings and advertising in publications such as the American Political Science Review.

We have also identified some practical questions for an author to ask when seeking a publisher. The answers to such inquiries can reveal a great deal about an editor's expectations for a project, its anticipated market, and the publisher's marketing approach. Such questions are:

1. What market(s) does the editor expect to reach with the project? Course adoptions? At what level(s)? Single-copy sales to libraries or to professionals?

2. How many copies would be printed, in cloth and in paper?

3 . What would the price(s) be?

4. What is the publisher's policy on review copies and exam copies?

In addition to speaking with an editor, authors should examine a publisher's frontlist and backlist, marketing materials, and exhibits. These can be valuable indicators of a company's products, approach, and effectiveness.

In order to sharpen the usefulness of our list, we asked two impertinent questions of our informants:

1. "If we code the market segments as (1) freshman; (2) sophomore; (3) junior; (4) senior; (5) masters; and (6) doctoral, indicate the major markets for your books.'

2. "We are known by the books that we have published in the past and would like to publish in the future. List three titles that you have worked on or have been responsible for, either at your current position or a previous one, in the past five years."

We hope this information will be helpful and that it will save both authors and publishers time, money, and effort. Because publishers and editors enter and leave the field with surprising frequency, our list cannot be static and we cannot vouch for its long-term inclusiveness. We regret any omissions and promise to amend future lists as further information is received.

\section{U.S. Publishers}

University of Alabama Press Malcolm M. MacDonald

Box 870380

Tuscaloosa, AL 35487

ph (205) 348-5180

fax (205) 348-9201

Markets: 4-5-6

Moen: Transformation of the Christian Right

Percy: Disability, Civil Rights, and Public Policy

Roeder: Public Opinion and Policy Leadership in the American States

The American University Press Christopher Kelaher 4400 Massachusetts Avenue, NW McKinley Hall, 350

Washington, DC 20016-8146

ph (202) 885-3409

fax (202) 885-1075

Markets: 3-4-5-6

Hancock et al.: Politics in Western Europe (Chatham House)

Trebach and Inciardi: Legalize It? Debating American Drug Policy

Odom: America's Military Revolution: Strategy and Structure after the Cold War

Basic Books

Kermit Hummel

10 E 53rd Street

New York, NY 10022 